\title{
Removal of TDS and TSS from Industrial Wastewater using Fly Ash
}

\author{
Nehal M. Ashour ${ }^{1}$, Mohamed Bassyouni ${ }^{2,3 *}$, Mamdouh Y. Saleh ${ }^{1}$ \\ ${ }^{1}$ Sanitary and Environmental Engineering, Department of Civil Engineering, Faculty of Engineering, Port Said University, Port Said 42526, Egypt \\ ${ }^{2}$ Department of Chemical Engineering, Faculty of Engineering, Port Said University, Port Said 42526, Egypt \\ ${ }^{3}$ Materials Science Program, University of Science and Technology, Zewail City of Science and Technology, October Gardens, 6th of October, Giza 12578, \\ Egypt
}

Received: 15/09/2020 Accepted: 17/11/2020_ Published: 20/03/2021

\begin{abstract}
Fly ash is one of the most abundant waste materials; its major components make it a potential agent for the adsorption of pollutants contaminants in water and wastewaters. In this study, fly ash obtained from burning of mazut was dried and sieved into different fractions $(600,300,150,75 \mu \mathrm{m})$. A pilot plant with an industrial discharge flow of 200L/hr was designed for reducing total Dissolved Solids (TDS), total suspended solids (TSS), conductivity and $\mathrm{pH}$ from industrial wastewater. The concentrations of (TDS), (TSS), conductivity and pH in industrial discharge flow had an average range of $80000,750,120000 \mathrm{mg} / \mathrm{L}$ and 13 respectively. The optimization of the treatment process using 5, 8, 12, $15 \mathrm{~g} / \mathrm{L}$ fly ash dosage had succeeded in improving the removal efficiency of (TDS), (TSS), conductivity and $\mathrm{pH}$ to $90 \%$, $92.3 \%, 90 \%$ and $93.5 \%$ respectively.
\end{abstract}

Keywords: Adsorbent; Wastewater; Fly ash, Low cost

\section{Introduction}

Industry contributes to the emission of large quantities of pollutants and increases the concentration of elements that cause water pollution and that harm living organisms [1]. Several methods are applied for the treatment of wastewater and water [210]. Adsorption is considered the most flexible technique among many methods used for the treatment of water and waste water. Scientists have found that the most used material for water and wastewater treatment is active carbon because it is highly effective for adsorption. [11]. If it is possible to convert some solid waste and agricultural waste into valuable applications such as absorbent materials used in treating sewage and water from pollutants, then it is one of the important and beneficial uses of that waste [12]. Given the solid waste as low-cost adsorbents can be used, emission controls can have a double-fold benefit. First, the amount of waste materials might be partially reduced, and second, if created, the low cost adsorbent might minimize wastewater pollution at economic cost. In order to extract different types of contaminants from water and wastewater, various industrial waste such as slag, fly ash, sludge and red mud are investigated as adsorbents.

Fly ash contains boron, selenium, manganese, arsenic, chromium, vanadium, sodium and cadmium in abundant quantities [13]. $\mathrm{Fe}_{2} \mathrm{O}_{3}, \mathrm{SO}_{3}, \mathrm{CaO}, \mathrm{Al}_{2} \mathrm{O}_{3}, \mathrm{MgO}, \mathrm{Na}_{2} \mathrm{O}, \mathrm{SiO}_{2}, \mathrm{TiO}_{2}$, and $\mathrm{K}_{2} \mathrm{O}$ are the most important constituents of fly ash[14]. The properties of fly ash differ according to the type of coal from which this ash was issued, as there are four different types of coal whose properties depend on the chemical composition, temperature, ash content and the origin of geological coal. Lignite, anthracite, sub-bituminous and bituminous are the most common type of coal. The composition of fly ash from burning bituminous is mostly calcium, magnesium and silica.

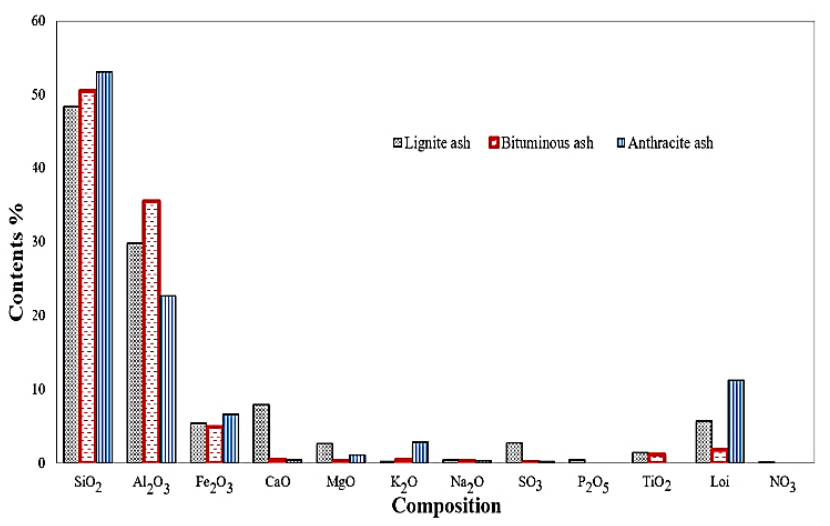

Figure 1: Lignite, anthracite coal and bituminous Chemical composition

*Corresponding author: Mohamed Bassyouni, (a) Department of Chemical Engineering, Faculty of Engineering, Port Said University, Port Said 42526, Egypt and (b) Materials Science Program, University of Science and Technology, Zewail City of Science and Technology, October Gardens, 6th of October, Giza 12578, Egypt. E-mail: migb2000@hotmail.com ; Tel.: +2-011-596-75357 
The extent to which fly ash contains calcium, silica, ammonia, and iron oxide defines the fly ash category, and they are two class classes $\mathrm{f}$ and $\mathrm{c}$, as it is the main difference between the two categories [15-16]. Fig. 1 displays the chemical composition of anthracite, bituminous, and lignite ash from coal. Fly ash can be used to separate heavy metals from wastewater as an adsorption method. [17-20]. The adsorption processes can be regulated using mass transfer, particle diffusion, chemical reactions and methods [21]. The key components in fly ash are $\mathrm{SiO}_{2}$ and $\mathrm{Al}_{2} \mathrm{O}_{3}$, where $\mathrm{SiO}_{2}$ material is more susceptible to heavy metal adsorption because of complex lone pair hybridization [22] or lone pair electron. Because of its high removal of different contaminants, such as many heavy metal elements, fly ash has demonstrated to scientists its high efficacy in the treatment of industrial and waste water, and scientists are currently looking to use effective methods to enhance the surface properties of fly ash to make it more capable and effective in removing pollutants. Chemical treatments using acid or alkali as well as physical methods such as laser, ultrasonic, microwave, or plasma therapy are among these methods. The mazut fly ash (MFA) is a combustion product produced by the burning of mazut at power stations. This fuel is a heavy residual oil of the petroleum refineries distillation or cracking units. MFA is obtained from flue gas purification machines. MFA is generally known as toxic waste; however, certain studies indicate that MFA inorganic matter can be of industrial value to recover useful elements, including $\mathrm{V}$ and $\mathrm{Ni}$ [22-28]. In fact, the carbonaceous fraction of MFA can be used as a black pigment for cementitious content production [29].

The composite composition of Total Dissolved Solids (TDS) is a mixture of both organic and inorganic compounds in a suspended chemical, ionized or micro-granular (colloidal) form. In general, the practical meaning is that the solids (often abbreviated TDS) must be low enough to withstand filtration by a two micrometer sieve size [30]. Complete hardness, organic ions, bicarbonate, alkalinity, sulphate, sodium, calcium, nitrate, magnesium, phosphate, iron, chloride and carbonate can be used. For aquatic life, a certain level of those ions is necessary in water. Changes in concentrations of TDS can be harmful. The flow of water into and out of an organism's cells is determined by water density. In industrial wastewater, steel production, pharmaceutical manufacturing, mining activities, oil and gas exploration, and food processing facilities are major sources of TDS. Furthermore, salts used for road deicing may make a major contribution to the charging of water sources by TDS. Concentrations of TDS in water vary in various geographical regions due to varying mineral solubility. Total solids values range between 30, 65 and 195: $1100 \mathrm{mg} / \mathrm{l}$ for water in contact with granite, rocky areas and sedimentary areas. [31-34]. The concentration of ions in the water gives it the ability to pass electric flow, and this property is expressed by electrical conductivity [35-36]. There is a strong direct relationship between the presence of ions in the water and between the conductivity, for example, water that contains a small number of ions has a weak conductivity, so we find that the distillate will not be used as an electrical insulator [37]. In contrast, water that contains a large number of ions is highly conductive, as is sea water, which is characterized by its high conductivity [38].

On account of their negative and positive charges, ions bear power [39]. They break into particles which are negatively charged (cation) and positively charged (anion) as electrolytes dissolve in water. As the dissolved compounds break in water, the amounts of each negative and positive charge remain equivalent. This means that while water conductivity increases with added ions, electrically neutral conductivity remains [40]. $\mathrm{pH}$ is similar to temperature; each of them has a specific value. The $\mathrm{pH}$ value ranges from 0 to 14 . As the number 7 expresses that water is neutral. The lower the number than 7 is an indication of the acidity of the water, and the higher the number than 7 , the more alkaline the water is $[41,42]$. The reason for the decrease in the $\mathrm{pH}$ below number 7 is due to the presence of hydrogen ions and the reason for the increase in the $\mathrm{pH}$ above number 7 due to the presence of hydroxyl ions. In neutral waters, the concentration of both hydrogen and hydroxyl ions is $10^{\wedge-7} \mathrm{M}$. For example, if the hydrogen concentration increases, the hydroxyl concentration decreases with it, and vice versa, so that their sum does not exceed $10^{\wedge-14}$ [43]. $\mathrm{pH}$ is very important for the life of living things in the water, as all of them will die if the $\mathrm{pH}$ drops or increases to a high degree. The $\mathrm{pH}$ has an effect on the presence of heavy and toxic metals in the water and their solubility in it. The best $\mathrm{pH}$ number suitable for living organisms in the water ranges between 6.5 and 9 [44-47].

\section{Materials and Methods \\ 2.1 Aim of Study}

Industries in developed countries have seen rapid growth in recent years. These factories discharge wastewater that carries high levels of dissolved solids and demand for chemical oxygen. These effluents, which comply with the regulations imposed on industrial sectors, should be handled for safe disposal. This research aims to improve the efficiency of TSS, TDS, Conductivity and $\mathrm{pH}$ removal of industrial wastewater by adding an inexpensive adsorbent such as fly ash.

\subsection{Preparation of adsorbent}

Raw fly ash was collected as a solid waste material from mazut burning, which used in one of the brick factories in Giza, Egypt. For the adsorption of contaminants from the industrial wastewater effluent, FA was used. FA collected from burning of mazut was dried and sieved into various fractions $(600,300,150$, $75 \mu \mathrm{m})$ using test sieve shaker (Endecott EF1) in soil and foundations laboratory, faculty of engineering, portsaid university, Egypt. The size fractions were preserved in glass bottles for use as an adsorbent. Fly ash with particle size of 300 $600 \mu \mathrm{m}$ was used in all the experiments.

\subsection{Model Description and Operation}

The work was performed on a scaled pilot plant in this research. Four tanks were composed of the model system used. Tank 1 is a Chemical feed unit made of galvanized tin sheets with capacity of $27 \mathrm{~L}(30 * 30 * 30 \mathrm{~cm})$. Tank 2 is a circular mixing tank made of galvanized tin sheets $(50 \mathrm{~cm}$ diameter and $10 \mathrm{~cm}$ depth). A motor was used for mixing with $100 \mathrm{rpm}$ in speed. Tank 3 is a circular sedimentation tank $(100 \mathrm{~cm}$ diameter and $15 \mathrm{~cm}$ depth) made of galvanized tin sheets. The settled fly ash was natural scared slowly to the bottom of the settling tank. Tank 4 is a glass tank with flow rate $=0.5 \mathrm{~m} 3 / \mathrm{m} 2 / \mathrm{hr}$. The designed filter is $(35$ $* 35 * 80 \mathrm{~cm} 3$ ) tank perforated at the bottom with 9 holes $0.5 \mathrm{~cm}$ in diameter for each. It was made from glass and contains a filtration media of two layers; a bottom layer of $20 \mathrm{~cm}$ in depth of gravel with gradation between $3 \mathrm{~mm}$ to $20 \mathrm{~mm}$ lays under a layer of sand with $30 \mathrm{~cm}$ in depth. 


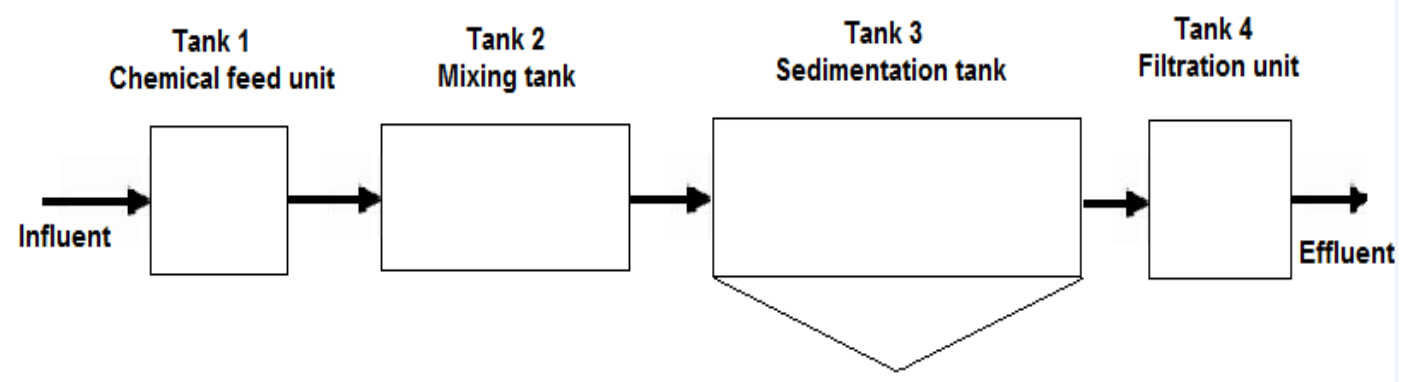

Figure 2. Flow chart of Pilot plant for the model

The mixing tank's total volume was $20 \mathrm{~L}$ with a detention time of 40 minutes. The volume of sedimentation tank is $120 \mathrm{~L}$. The water stays for an hour in this tank. With a constant temperature, the water flow was $200 \mathrm{~L} / \mathrm{hr}$ as shown in Figure 2.

\subsection{Sample Collection Points}

The pilot plant had two collection points for the samples. To analyze the characteristics of wastewater, those points were very significant. The positions were first, the pilot plant influential; second, the downstream pilot plant effluent from the filtration unit.

\section{Experimentation \\ 3.1. Experimental Work}

The dosages of FA used, in mixing tank, ranged from $5 \mathrm{~g} / \mathrm{L}$ to $15 \mathrm{~g} / \mathrm{L}$ followed by 40 minutes of shaking with speed of 100 rpm. After shaking of the samples they were subjected to analysis. After that stage of mixing with adsorbent goes to the filtration unit. The experimental work was divided into four groups using FA (with dosages of 5, 8, 12 and $15 \mathrm{~g} / \mathrm{L}$ ) each group was carried out in 8 days and samples were collected 3 times each day.

\subsection{Analysis of Wastewater}

In this research, the parameters of the industrial wastewater were measured before being treated and entered into the pilot plant, and the influential water produced after the treatment process was also measured. Water samples coming out of this model were collected over a 24-hour period and mixed well before measure. The samples were taken at 9.00 a.m. three times a day, at $11.00 \mathrm{a} . \mathrm{m}$. at daily intervals. And, at 1.00 p.m., the peak time was contaminated.

\subsubsection{Total dissolved solids (TDS)}

Dissolved solids are considered the solids found in the filtrate that passes through a filter with a nominal pore size of $2 \mu \mathrm{m}$ or less. The conductivity electrode was used to assess the quantity of the dissolved solids in the influential wastewater from the filter to the mixing tank and the effluent, and calculated by ppm.

\subsubsection{Total suspended solids (TSS)}

This test used to measure the quantity of the suspended solids in the influent wastewater to the mixing tank and the effluent from the filter. The theory of this test is the residue that is ignited to $550+50^{\circ} \mathrm{C}$ from the filtered sample. The remaining solids are the stable suspended solids while the volatile solids are the weight lost after ignition.

\subsubsection{Conductivity}

The conductivity electrode was used to determine the quantity of the dissolved solids in the influent wastewater to the mixing tank and the effluent from the filter.

\subsection{4. $\mathrm{pH}$-value}

The $\mathrm{pH}$-value is the acid or base intensity measured on a scale from 0.0 to 14.0. Technically it is the logarithm equivalent of the concentration of hydrogen ions. The $\mathrm{pH}$-value was measured for the influent to the mixing tank without chemicals addition and the effluent from the filter. The $\mathrm{pH}$-value was measured using the "Digital $\mathrm{pH}$ meter" For $\mathrm{pH}$-value determinations the meter was calibrated using buffers of 4.0, 6.86 and 9.18 .

\section{Results and Discussion 4.1 Effect of FA dose}

As shown in Figure 3, the percent removal of pollutants increased with the increase in the adsorbent dosage due to the increase in the area of the adsorbent surface. At the $15 \mathrm{~g} / \mathrm{l}$ adsorbent concentration for TDS, TSS, conductivity and $\mathrm{pH}$, the maximum average removal rate of $88.6,91.44,88,90.08$ percent occurred.

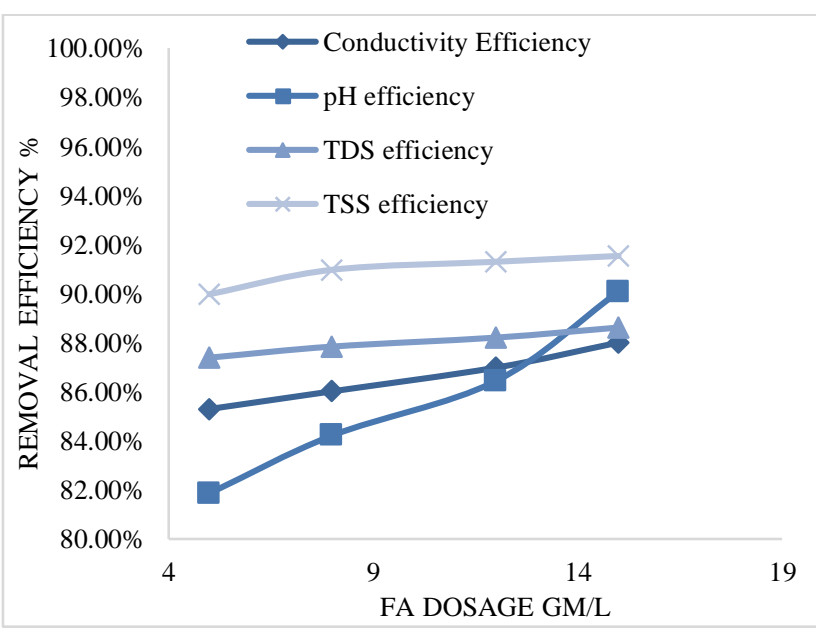

Figure 3: Effect of FA dose on pollutants removal

\subsubsection{TDS}

The total dissolved solids (TDS) of the influent during the 8 days ranged from $29110 \mathrm{mg} / \mathrm{l}$ to $90210 \mathrm{~g} / \mathrm{l}$ with average of 62366 $\mathrm{mg} / \mathrm{l}$. After treatment, the TDS of the effluent ranged from 4321 
$\mathrm{mg} / \mathrm{l}$ to $10110 \mathrm{mg} / \mathrm{l}$ with average of $7094 \mathrm{mg} / \mathrm{l}$ and maximum efficiency of removal equals to $90.25 \%$ occurs at max TDS influent with $15 \mathrm{~g} / \mathrm{l} \mathrm{FA}$ dose. These results prove that FA is very effective in removing TDS due to accumulation of atoms on the surface area of the adsorbent (FA) and concentration of these materials. Figure 4. Shows difference between TDS concentration values in influent and effluent for the different FA doses. Figure 5. Shows difference between TDS removal efficiency for the different FA doses. Figure 6. Shows difference between $\mathrm{q} \mathrm{mg} / \mathrm{g}$ values for the different FA doses.

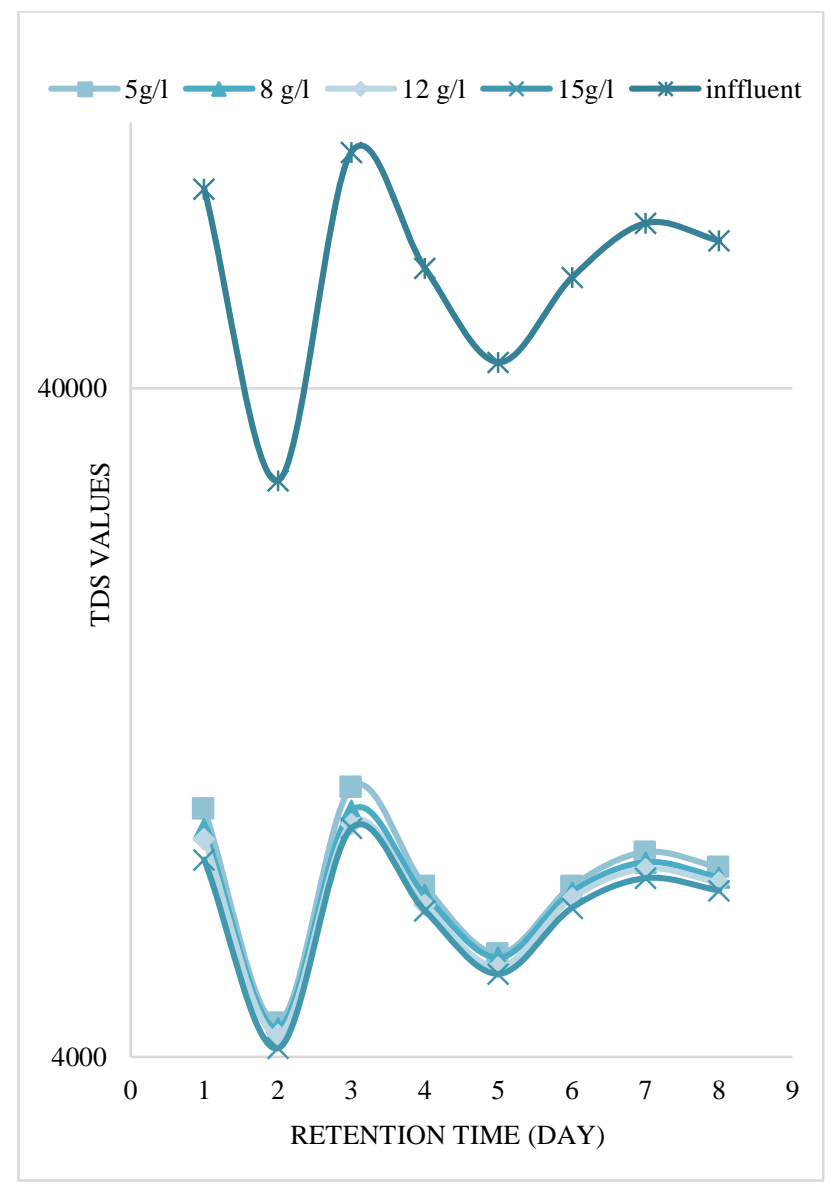

Figure 4: TDS concentration values in influent and effluent for the different FA doses

\subsubsection{TSS}

The total suspended solids (TSS) of the influent during the 8 days ranged from $310 \mathrm{mg} / \mathrm{l}$ to $750 \mathrm{~g} / \mathrm{l}$ with average of $572 \mathrm{mg} / \mathrm{l}$. After treatment, the TDS of the effluent ranged from $35 \mathrm{mg} / \mathrm{l}$ to $72 \mathrm{mg} / \mathrm{l}$ with average of $51 \mathrm{mg} / \mathrm{l}$ and maximum efficiency of removal equals to $92.62 \%$ occurs at $15 \mathrm{~g} / \mathrm{l} \mathrm{FA}$ dose. These results prove that FA is very effective in removing TSS due to accumulation of atoms on the surface area of the adsorbent (FA) and concentration of these materials. Figure 7. Shows difference between TSS concentration values in influent and effluent for the different FA doses. Figure 8. Shows difference between TSS removal efficiency for the different FA doses. Figure 9. Shows difference between $\mathrm{q} \mathrm{mg} / \mathrm{g}$ values for the different FA doses.



Figure 5: TDS removal efficiency for the different FA doses



Figure 6: $\mathrm{q} \mathrm{mg} / \mathrm{g}$ values for the different FA doses

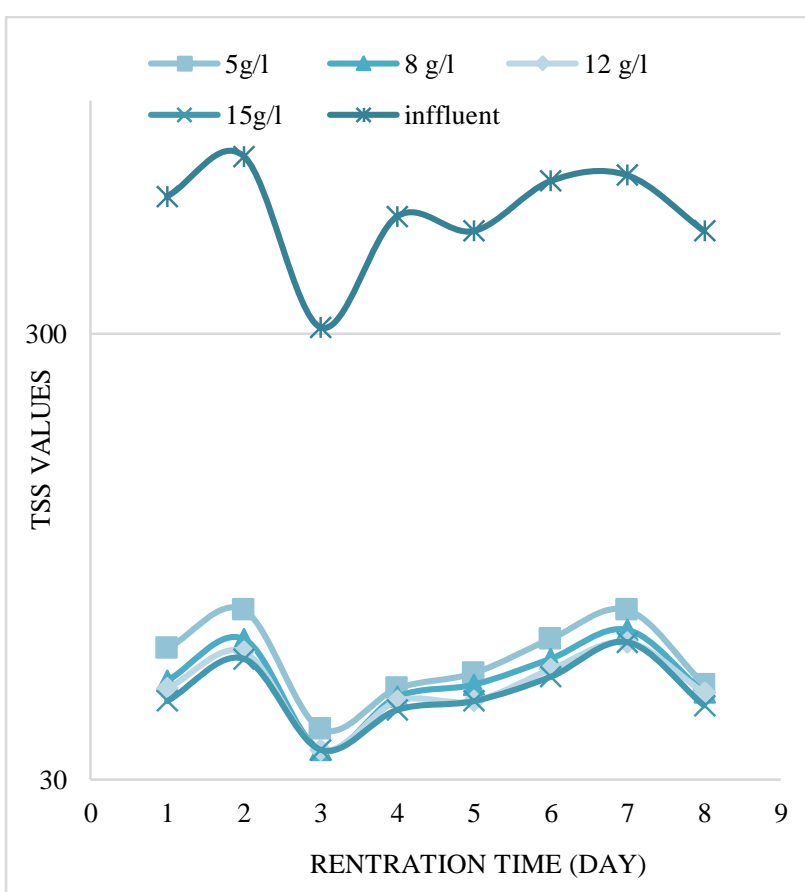

Figure 7: TSS concentration values in influent and effluent for the different FA doses 


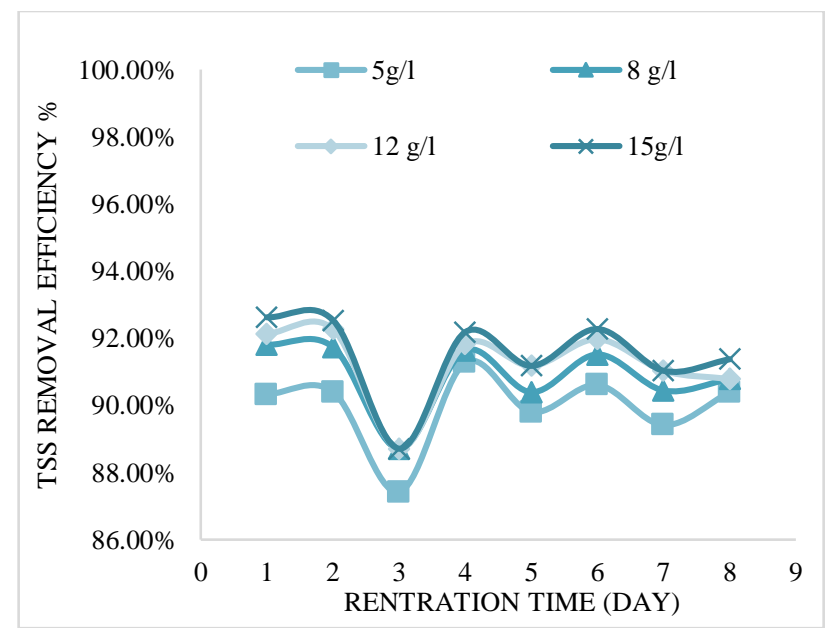

Figure 8: TSS removal efficiency for the different FA doses

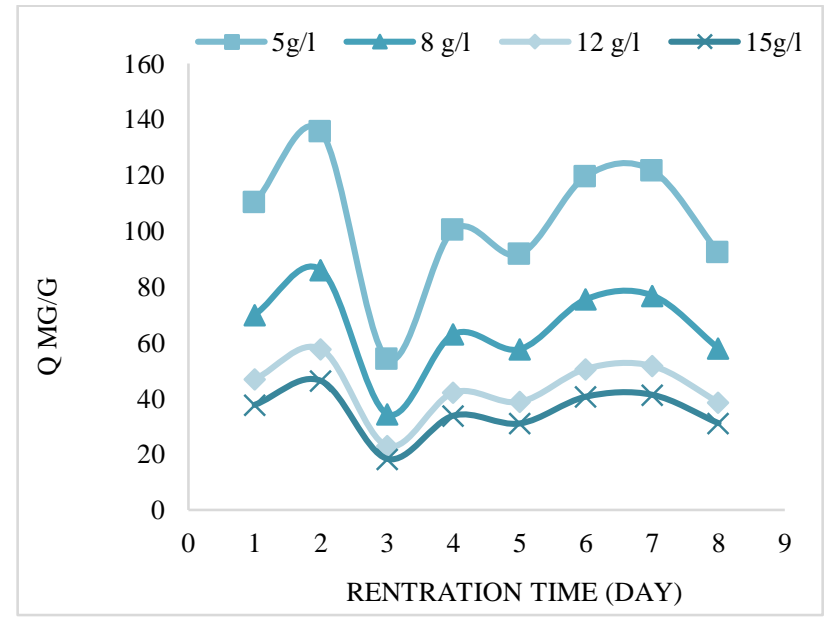

Figure 9: $\mathrm{q} \mathrm{mg} / \mathrm{g}$ values for the different FA doses

\subsubsection{Conductivity}

The Conductivity of the influent during the 8 days ranged from 45500 to $130700 \mathrm{~g} / \mathrm{l}$ with average of 90863 . After treatment, the Conductivity of the effluent ranged from 14990 to 2660 with average of 11837 and maximum efficiency of removal equals to $90.49 \%$ occurs at $15 \mathrm{~g} / \mathrm{l} \mathrm{FA}$ dose. These results prove that FA is very effective in reducing conductivity due to accumulation of atoms on the surface area of the adsorbent (FA) and concentration of these materials. The fly ash adsorbed heavy metals from industrial wastewater, reducing the electrical conductivity. Figure 10. Shows difference between Conductivity values in influent and effluent for the different FA doses. Figure 11. Shows difference between Conductivity removal efficiency for the different FA doses.



Figure 10: Conductivity values in influent and effluent for the different FA doses



Figure 11: Conductivity removal efficiency for the different FA doses

\subsection{4 $\mathrm{pH}$}

$\mathrm{pH}$ of the influent during the 8 days ranged from 10.8 to 12.8 with average of 11.8. After treatment, the $\mathrm{pH}$ of the effluent ranged from 7.3 to 8.1 with average of 7.6 and maximum efficiency of removal equals to $93.5 \%$ occurs at $15 \mathrm{~g} / \mathrm{l} \mathrm{FA}$ dose. These results prove that FA is very effective in removing $\mathrm{pH}$ due to accumulation of atoms on the surface area of the adsorbent (FA) and concentration of these materials. Figure 12. Shows difference between $\mathrm{pH}$ values in influent and effluent for the different FA doses. Figure 13. Shows difference between $\mathrm{pH}$ removal efficiency for the different FA doses. 


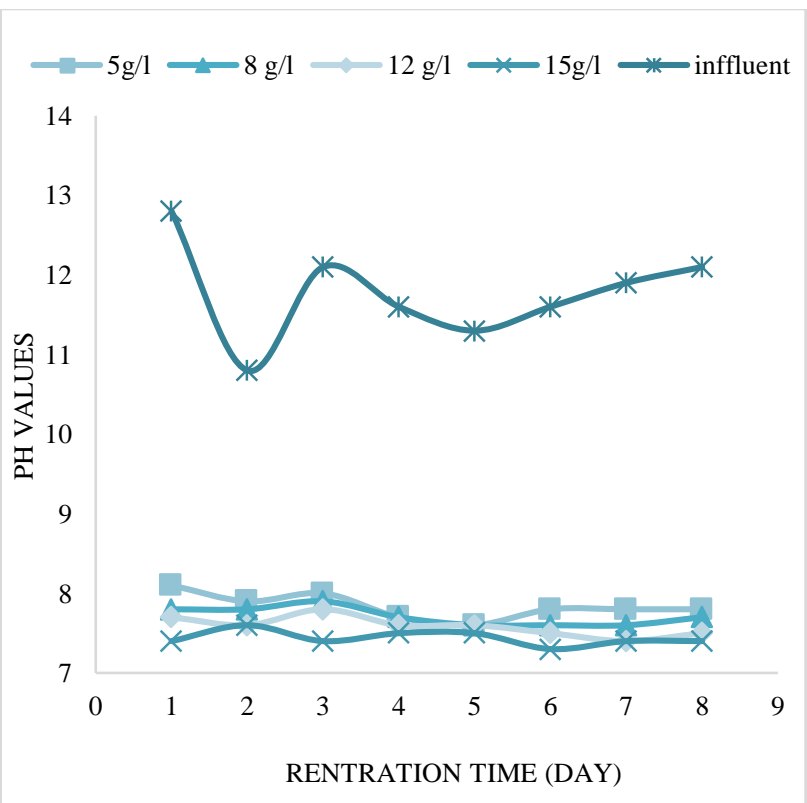

Figure 12: $\mathrm{pH}$ values in influent and effluent for the different FA doses

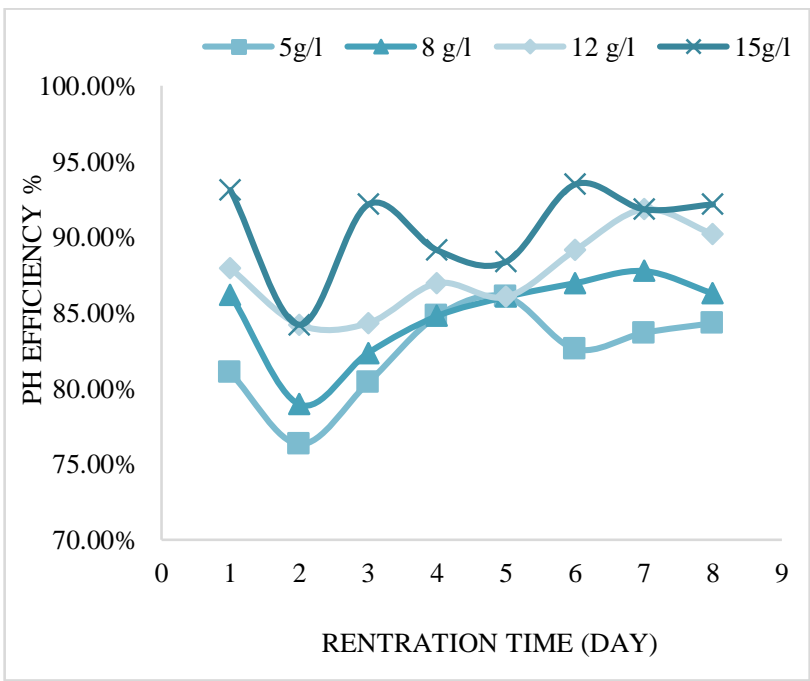

Figure 13: $\mathrm{pH}$ values in influent and effluent for the different FA doses

\section{Conclusion}

The Fly ash with particle size of 300-600 $\mu \mathrm{m}$ achieved high sedimentation efficiency and did not produce particles floating on the surface. The detention time of 30 minutes in the tank was sufficient for mixing and one hour for the total sedimentation. The most effective dosage in removing TDS was $15 \mathrm{~g} / \mathrm{l}$ of FA. $90 \%$ of TDS were removed using this dosage. The increasing in the influent TDS values the increasing in removal efficiency. The highest efficiency of TSS removal was observed in the fourth dosage (dosage $=15 \mathrm{gll}$ of FA \& $\eta=92.3 \%$ ). The highest efficiency of conductivity removal was observed in the fourth dosage (dosage $=15 \mathrm{gll}$ of FA \& $\eta=90 \%$ ). The highest efficiency of $\mathrm{pH}$ was observed in the fourth dosage (dosage $=15 \mathrm{gl}$ of FA \& $\eta=93 \%)$.

\section{Ethical issue}

Authors are aware of, and comply with, best practice in publication ethics specifically with regard to authorship (avoidance of guest authorship), dual submission, manipulation of figures, competing interests and compliance with policies on research ethics. Authors adhere to publication requirements that submitted work is original and has not been published elsewhere in any language.

\section{Competing interests}

The authors declare that there is no conflict of interest that would prejudice the impartiality of this scientific work.

\section{Authors' contribution}

All authors of this study have a complete contribution for data collection, data analyses and manuscript writing.

\section{References}

1 Elhady, Sarah, Mohamed Bassyouni, Ramadan A. Mansour, Medhat H. Elzahar, Shereen Abdel-Hamid, Yasser Elhenawy, and Mamdou Y. Saleh. "Oily Wastewater Treatment Using Polyamide Thin Film Composite Membrane Technology." Membranes 10, no. 5 (2020): 84.

2 Bassyouni, M., M. H. Abdel-Aziz, M. Sh Zoromba, S. M. S. AbdelHamid, and Enrico Drioli. "A review of polymeric nanocomposite membranes for water purification." Journal of Industrial and Engineering Chemistry 73 (2019): 19-46.

3 Zoromba, M. Sh, Mohamed IM Ismail, M. Bassyouni, M. H. AbdelAziz, Numan Salah, Ahmed Alshahrie, and Adnan Memic. "Fabrication and characterization of poly (aniline-co-o-anthranilic acid)/magnetite nanocomposites and their application in wastewater treatment." Colloids and Surfaces A: Physicochemical and Engineering Aspects 520 (2017): 121-130.

4 Elrasheedy, Asmaa, Norhan Nady, Mohamed Bassyouni, and Ahmed El-Shazly. "Metal organic framework based polymer mixed matrix membranes: Review on applications in water purification." Membranes 9, no. 7 (2019): 88.

5 Elminshawy, Nabil AS, M. El-Ghandour, Y. Elhenawy, M. Bassyouni, D. G. El-Damhogi, and Mohammad F. Addas. "Experimental investigation of a V-trough PV concentrator integrated with a buried water heat exchanger cooling system." Solar Energy 193 (2019): 706-714.

6 Gutub, Saud A., M. Bassyouni, and S. M. S. Abdel-Hamid. "Dissolved solids adsorption of freshwater using synthesized biofoam composite." Life Science Journal 10, no. 2 (2013): 464-471.

7 Abdel-Aziz, M. H., E. S. Z. El-Ashtoukhy, M. Sh Zoromba, and M. Bassyouni. "Oil-in-water emulsion breaking by electrocoagulation in a modified electrochemical cell." Int. J. Electrochem. Sci 11 (2016): 9634-9643.

8 Abdel-Aziz, M. H., E. S. Z. El-Ashtoukhy, M. Sh Zoromba, and M. Bassyouni. "Oil-in-water emulsion breaking by electrocoagulation in a modified electrochemical cell." Int. J. Electrochem. Sci 11 (2016): 9634-9643.

9 Fouad, Kareem, Mohamed Gar Alalm, Mohamed Bassyouni, and Mamdouh Y. Saleh. "A novel photocatalytic reactor for the extended reuse of $\mathrm{W}-\mathrm{TiO} 2$ in the degradation of sulfamethazine." Chemosphere (2020): 127270.

10 Elminshawy, Nabil AS, Mamdouh A. Gadalla, M. Bassyouni, Kamal El-Nahhas, Ahmed Elminshawy, and Y. Elhenawy. "A novel concentrated photovoltaic-driven membrane distillation hybrid system for the simultaneous production of electricity and potable water." Renewable Energy 162 (2020): 802-817.

11 C. G. Rocha, D. A. Zaia, R. V. Alfaya, and A. A. Alfaya, "Use of rice straw as biosorbent for removal of $\mathrm{Cu}(\mathrm{II}), \mathrm{Zn}(\mathrm{II}), \mathrm{Cd}(\mathrm{II})$ and $\mathrm{Hg}$ (II) 
ions in industrial effluents," Journal of Hazardous Materials, vol. 166, no. 1, pp. 383-388, 2009.

12 Abdel-Hamid, S. M. S., O. A. Al-Qabandi, Elminshawy NAS, M. Bassyouni, M. S. Zoromba, M. H. Abdel-Aziz, and H. Mira. "Fabrication and Characterization of Microcellular Polyurethane Sisal Biocomposites." Molecules 24, no. 24 (2019): 4585.

13 Bhatnagar, Amit, Vítor JP Vilar, Cidália MS Botelho, and Rui AR Boaventura. "A review of the use of red mud as adsorbent for the removal of toxic pollutants from water and wastewater." Environmental technology 32, no. 3 (2011): 231-249.

14 Lokeshappa, B., Dikshit, A.K., 2011. Disposal and Management of Fly Ash. International Conference on Life Science and Technology, vol. 3. IPCBEE, Singapore.

15 Bhatt, M.S., 2006. Effect of ash in coal on the performance of coal fired thermal power plants. Part I: primary energy effects. Energy Sources Part A 28, 25e41.

16 ASTMC 204, 1994. Test Method for Fineness of Portland Cement by Air Permeability Apparatus, Volume 04.02. American Society for Testing and Materials, Annual Book of ASTM Standards, West Conshohocken, Pennsylvania.

17 Ram, L.C., Masto, R.E., 2010. An appraisal of the potential use of fly ash for reclaiming coal mine spoil. J. Environ. Manag. 91 (3), $603 \mathrm{e} 617$.

18 C.H. Weng, C. P. Huang, Adsorption characteristics of Zn (II) from dilute aqueous solution by fly ash, Colloid Surface A, 247 (2004) 137- 143

19 K.S. Hui, C.Y.H. Chao, S.C. Kot, Removal of mixed heavy metal ions in wastewater by zeolite $4 \mathrm{~A}$ and residual products from recycled coal fly ash, J Hazard Mater, 127 (2005) 89-101

20 I.J. Alinnor, Adsorptionof Heavy metal ions from aqueous solution by fly ash, Fuel, 86 (2007) 853-857

21 Y.C. Sharma, U.S.N. Singh, P.F. Gode, Fly ash for the removal of $\mathrm{Mn}(\mathrm{II})$ from aqueous solutions and wastewaters, Chem Eng J, 132(2007) 319-323

22 N. Unlu, M. Ersoz, Adsorption characteristics of heavy metal ions onto a low cost biopolymeric sorbent from aqueous solutions, J Hazard Mater, 136 (2006) 272-280

23 B. Bayat, Comparative study of adsorption properties of turkish fly ashes, I. The case of nickel (II), copper (II) and Zinc (II), J Hazard Mater, 95 (2002) 251-273

24 Yu Y. T., B. G. Kim, Y. Y. Choi, S. Y. Hong, S. K. Hwang, J. H. Park (1996) J. Korea Solid Wastes Engineering Society, 13, No 2, 236 246.

25 Vassileva CG, Daher DF, Vassilev SV. Chemical and phase-mineral composition of mazut fly ash and slag generated from a Syrian power plant. Comptes rendus de l'Académie bulgare des Sciences. 2015 Jan $1 ; 68(10)$.

26 Vitolo S, Seggiani M, Falaschi F. Recovery of vanadium from a previously burned heavy oil fly ash. Hydrometallurgy. $2001 \mathrm{Dec}$ $1 ; 62(3): 145-50$

27 Amer AM. Processing of Egyptian boiler-ash for extraction of vanadium and nickel. Waste Management. 2002 Aug 1;22(5):515-20.

28 Vassileva CG, Daher DF, Vassilev SV. Chemical and phase-mineral composition of mazut fly ash and slag generated from a Syrian power plant. Comptes rendus de l'Académie bulgare des Sciences. 2015 Jan $1 ; 68(10)$.

29 Reijnders L. Disposal, uses and treatments of combustion ashes: a review. Resources, Conservation and Recycling. 2005 Feb 1;43(3):313-36.

30 Al-Ghouti MA, Al-Degs YS, Ghrair A, Khoury H, Ziedan M. Extraction and separation of vanadium and nickel from fly ash produced in heavy fuel power plants. Chemical Engineering Journal. 2011 Sep 1;173(1):191-7.

31 Vassileva CG, Daher DF, Vassilev SV. Chemical and phase-mineral composition of mazut fly ash and slag generated from a Syrian power plant. Comptes rendus de l'Académie bulgare des Sciences. 2015 Jan $1 ; 68(10)$.
32 Saleh MY, Enany GE, Elzahar MH, Elshikhipy MZ, Hamouda R. Removal of lead in high rate activated sludge system. International Journal of Environmental and Ecological Engineering. 2014 Mar $1 ; 8(4): 413-8$

33 Rainwater FH, Thatcher LL. Methods for collection and analysis of water samples. US Government Printing Office; 1960.

34 Kormondy, E.J.: Concepts of ecology. Prentice-Hall, Englewood Cliffs, NJ. p. 182 (1969).

35 Garrison Investigative Board. Water quality report (Appendix A). Garrison Diversion Study, report to the International Joint Commission (1977).

36 Durfor, C.J. and Becker, E.: Constituents and properties of water.In: Water quality in a stressed environment: readings in environmental hydrology. W.A. Pettyjohn (ed.). Burgess Publishing Company, Minneapolis, MN (1972).

37 EPA. (2012). 5.9 Conductivity. In Water: Monitoring and Assessment. from http://water.epa.gov/type/rsl/monitoring/vms59.cfm

38 Milliequivalents, Millimoles, and Milliosmoles (Powerpoint). (n.d.). In University of Michigan. Retrieved from http://sitemaker.umich.edu/tutorial/files/handout_milliequiv.pd $\mathrm{f}$

39 Perlman, H. (2014). Electrical Conductivity and Water. In The USGS Water Science School. Retrieved from http://ga.water.usgs.gov/edu/electrical-conductivity.html

40 Miller, R. L., Bradford, W. L., \& Peters, N. E. (1988). Specific Conductance: Theoretical Considerations and Application to Analytical Quality Control. In U.S. Geological Survey Water-Supply Paper. Retrieved from http://pubs.usgs.gov/wsp/2311/report.pdf

41 Merriam-Webster. (2013). pH. In Merriam-Webster Dictionary . Retrieved from http://www.merriam-webster.com/dictionary/ph

42 Ophardt, C. E. (2003). pH. In Virtual Chembook. Retrieved from http://www.elmhurst.edu/ chm/vchembook/184ph.htm

43 USGS. (2013). Water Properties: pH. In The USGS Water Science School . Retrieved from http://ga.water.usgs.gov/edu/ph.html

44 Mabrouk, Abdel Nasser, Yasser Elhenawy, Mohamed Abdelkader, and Mohamed Shatat. "The impact of baffle orientation on the performance of the hollow fiber membrane distillation." Desalin. Water Treat 58 (2017): 35-45.

\section{Author Profile}



Nehal Ashour is a teaching assistant in the Civil Engineering Department, Faculty of Engineering, Port Said University, Port Said, Egypt.

Mohamed Bassyouni is a Professor of Chemical Engineering. He has completed a postdoctoral at TU-Clausthal, Germany in the area of materials processing. He holds a Ph.D. in Chemical Engineering, Cairo University. He received his master degree in Environmental Engineering from TU-HH, Germany. He obtained his undergraduate degree in Chemical Engineering. He is a member of the Editorial Board of International Institute of Chemical Biological and Environmental Engineering and the journal of Engineering-Port Said University. He won the 2014 Dr. Venice Kamel Award (Academic of Scientific Research and Technology) for Scientific Creativity for Young Researchers in the field of materials science and its applications. 


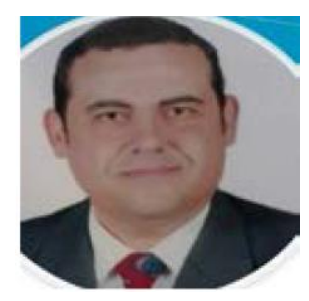

Mamdouh Youssif Saleh is a professor in the Civil Engineering Department, specializing in sanitary and environmental engineering with an emphasis on wastewater treatment since 2009. His research focuses on using A-B waste activated sludge system for wastewater treatment. He was born in Port Said, Egypt in 1961. He was graduated from Faculty of Engineering, Suez Canal University in 1985 . He received his M.Sc. degree in civil engineering from Suez Canal University, 1990. His got his Ph.D. degree in sanitary and environmental engineering in 1994, and completed via a cooperative research program between Suez Canal University, Port Said, Egypt and Aachen University, Aachen, Germany. He has more than 22 international journal/conference papers published. 